\title{
METALOGRAFSKA PREISKAVA IN KOROZIJSKA ODPORNOST ZVAROV FERITNEGA NERJAVNEGA JEKLA
}

\author{
METALLOGRAPHIC INVESTIGATION AND CORROSION \\ RESISTANCE OF WELDS OF FERRITIC STAINLESS STEELS
}

\author{
Matjaž Torkar, Aleksandra Kocijan, Roman Celin, Jaka Burja, Bojan Podgornik \\ Inštitut za kovinske materiale in tehnologije, Lepi pot 11, 1000 Ljubljana, Slovenija \\ matjaz.torkar@imt.si \\ Prejem rokopisa - received: 2016-04-04; sprejem za objavo - accepted for publication: 2016-05-12
}

doi:10.17222/mit.2016.059

\begin{abstract}
Preiskovani so bili vzorci zvarov feritnega nerjavnega jekla X6Cr17 (W.Nr. 1.4016). Prikazane so metalografske značilnosti prečnega in krožnega zvara. Določena je bila hitrost korozije v dveh korozijskih medijih in pri dveh temperaturah. Predstavljeni so rezultati osnovnega materiala, dveh zvarov in dveh primerjalnih materialov, jekla X2CrTi17 in maloogljičnega jekla DC01 EN10130. Rezultati preiskave so pokazali, da se v zvaru poveča velikost zrn, po mejah zrn pa je izločena martenzitna faza, oboje pa vpliva na korozijsko obstojnost. Nobeden od preiskovanih vzorcev ni pokazal izrazite pasivacije površine pri elektrokemijskem korozijskem preizkusu.

Ključne besede: feritno nerjavno jeklo, metalografija, zvar, korozijska odpornost

Samples of welds made from the ferritic stainless steel X6Cr17 (W.Nr. 1.4016) were investigated. Here we present the results of the metallographic charaterisations of these welds. We determined the corrosion rate in two corrosion media at two temperatures. The results from the base material and two welds are presented and compared with the steel X2CrTi17 and the low-carbon steel DC01 EN10130. The results revealed enlarged grains in the weld and martensite at the grain boundaries, both have an influence on the corrosion resistance. None of the investigated samples showed distinctive passivation of the surfaces during the electrochemical corrosion tests.

Keywords: ferritic stainless steel, metallography, weld, corrosion resistance
\end{abstract}

\section{UVOD}

Feritna nerjavna jekla so poceni, cenovno stabilna in korozijsko odporna jekla. Uporaba teh nerjavnih jekel je pogosta $\mathrm{v}$ avtomobilski industriji, pri izdelavi kuhinjskih pripomočkov in naprav ter tudi na drugih področjih. Feritna nerjavna jekla se zaradi njihove dobre toplotne prevodnosti in majhnega toplotnega raztezka uporabljajo tako za izdelavo dimnikov, glušnikov, izpušnih sistemov, pritrdilnih elementov, kot tudi za grelne elemente, ki se jih uporablja v kopelih staljene soli za toplotno obdelavo, $\mathrm{v}$ konstrukcijske namene in podobno. ${ }^{1-5}$

Pri visokih temperaturah iz taline nastaja faza delta ferita $(\delta)$, ki se potem ko kristalizira, pri ohlajanju ne spremeni. Te popolnoma feritne mikrostrukture se ne da toplotno obdelati. Neprisotnost fazne premene razloži, zakaj so pri ogrevanju ta jekla nagnjena k rasti zrn.

Feritna faza $\mathrm{v}$ zvaru in toplotno vplivana cona sta občutljivi na intersticijske elemente, kot sta ogljik in dušik, ki pri visokih temperaturah $\mathrm{z}$ difuzijo spremenita feritno fazo $v$ avstenit. Ta avstenit pa se pri ohlajanju po mejah zrn pretvori v martenzit (krhek). Dodaten problem je tudi $\mathrm{z}$ rastjo zrn $\mathrm{v}$ toplotno vplivani coni in $\mathrm{v}$ zvaru. ${ }^{6,7}$ Za zadržanje duktilnosti feritne strukture, ki vsebuje tudi martenzit, je potrebno izvršiti toplotno obdelavo čim prej po zaključnem varjenju. Ta obdelava za odpravo napetosti se izvede pri maksimalni temperaturi $750-800{ }^{\circ} \mathrm{C}$, kar je malo pod temperaturo nastanka avstenita $\mathrm{v}$ področjih bogatih $\mathrm{z}$ ogljikom. Namen te obdelave je popustiti martenzit, zmanjšati zaostale napetosti $\mathrm{v}$ zvaru ter povečati žilavost zvarnega spoja in toplotno vplivane cone.

Za preprečitev rasti zrn in pojava avstenitizacije je potrebno varjenje izvršiti $\mathrm{z}$ majhnim vnosom toplote $(1 \mathrm{~kJ} / \mathrm{mm}) .^{8}$

Študija korozijske odpornosti zvarov je izredno pomembna za uspešno uporabo feritnih nerjavnih jekel. Poleg obnašanja samega materiala v korozijskem mediju, je pomembna tudi korozijska odpornost zvarnih spojev. Literatura $^{9}$, navaja, da je korozijska odpornost zvarov odvisna tudi od velikosti zrn in prisotnosti različnih faz v mikrostrukturi zvara.

Namen predstavljene preiskave je z metalografsko preiskavo ugotoviti mikrostrukturne značilnosti dveh vrst zvarov ter napraviti primerjavo s preizkusom korozijske odpornosti osnovnega materiala, zvarov in primerjalnih materialov v dveh korozijskih medijih.

Dobljeni podatki naj bi služili optimiranju tehnologije varjenja feritnega nerjavnega jekla in naj bi prispevali $\mathrm{k}$ podaljšanju zdržljivosti zvarov $\mathrm{v}$ danem korozijskem mediju. 


\section{OPIS VZORCEV}

Vzorci, prikazani na Sliki 1, so bili odrezani iz kadi in označeni kot "prečni zvar", izveden prečno na dno kadi in "krožni zvar", izveden po obodu kadi. Obod in dno kadi sta izdelana iz enakega feritnega nerjavnega jekla X6Cr17, prečni in krožni zvar pa sta izdelana $\mathrm{z}$ različnimi varilniki, zaradi česar je potrebno napraviti tudi primerjavo med posameznimi zvari. Dno kadi se na sliki 1 vidi slabo, ker je pravokotno na obod kadi in je označen z belo puščico.

Za primerjavo korozijskih hitrosti sta bila dodatno preizkušena še vzorec malo ogljične pločevine kvalitete DC01 po standardu EN10130 in vzorec pločevine feritnega nerjavnega jekla X2CrTi17. Nominalna kemijska sestava za preiskovana jekla je podana v Tabeli $\mathbf{1}$.

\section{EKSPERIMENTALNO DELO}

Zvari so bili izdelani po postopku TIG (Tungsten inert gas welding), brez dodajanja materiala.

Odrezani so bili vzorci zvarov (jeklo X6Cr17) in pripravljeni so bili za metalografsko preiskavo po standardnem postopku $\mathrm{z}$ zalivanjem $\mathrm{v}$ maso, brušenjem in poliranjem. Za metalografsko preiskavo so bili vzorci jedkani z Vilella jedkalom $\left(5 \mathrm{~cm}^{3} \mathrm{HCl}, 2 \mathrm{~g}\right.$ pikrinske kisline in $100 \mathrm{~cm}^{3}$ etil alkohola).

Izvedena je bila metalografska preiskava obeh vrst zvarov; prečnega in krožnega zvara. Mikrostruktura je bila pregledana s pomočjo svetlobne mikroskopije, s svetlobnim mikroskopom Nikon Microphot FXA,

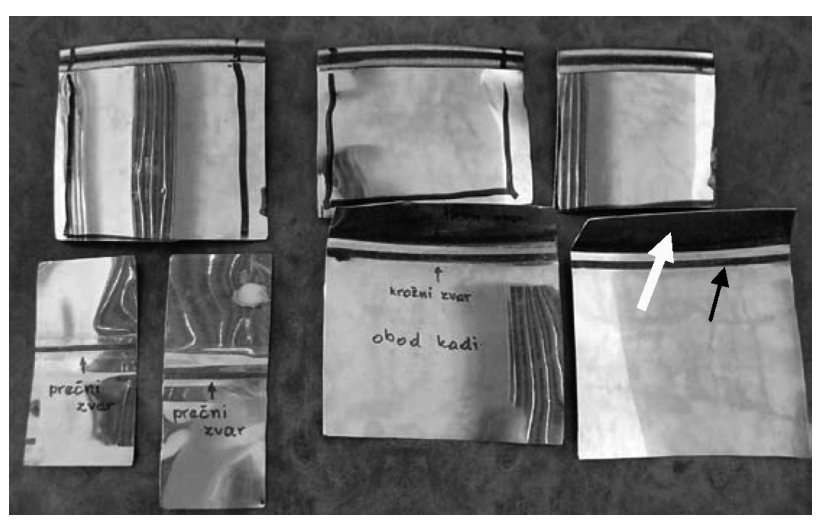

Slika 1: Vzorci s prečnim in krožnim zvarom. Jeklo X6Cr17. Svetla puščica označuje dno kadi, črna puščica pa krožni zvar.

Figure 1: Samples with cross and circular weld. Steel X6Cr17. White arrow indicates the bottom of the tub, the black arrow indicates the circular weld.

Tabela 1: Nominalna kemijska sestava za preiskovana jekla

Table 1: Nominal chemical composition for investigated steels

\begin{tabular}{|c|c|c|c|c|c|c|c|c|c|}
\hline Jeklo & C (max.) & $\begin{array}{c}\text { Si } \\
(\max .)\end{array}$ & $\begin{array}{c}\text { Mn } \\
(\max .)\end{array}$ & $\begin{array}{c}\text { P } \\
(\max .)\end{array}$ & $\begin{array}{c}\text { S } \\
(\max .)\end{array}$ & $\begin{array}{c}\text { Cr } \\
(\max .)\end{array}$ & $\begin{array}{c}\text { Al } \\
(\max .)\end{array}$ & / \\
\hline X6Cr17 & 0,08 & 1,0 & 1,0 & 0,040 & 0,015 & $16-18$ & $/$ & $/$ \\
\hline X2CrTi17 & 0,025 & 0,50 & 0,5 & 0,040 & 0,015 & $16-18$ & 0,015 & $0,3-0,6$ & $/$ \\
\hline DC01 & 0,12 & 0,03 & 0,6 & 0,045 & 0,045 & $/$ & $/$ & $/$ \\
\hline
\end{tabular}

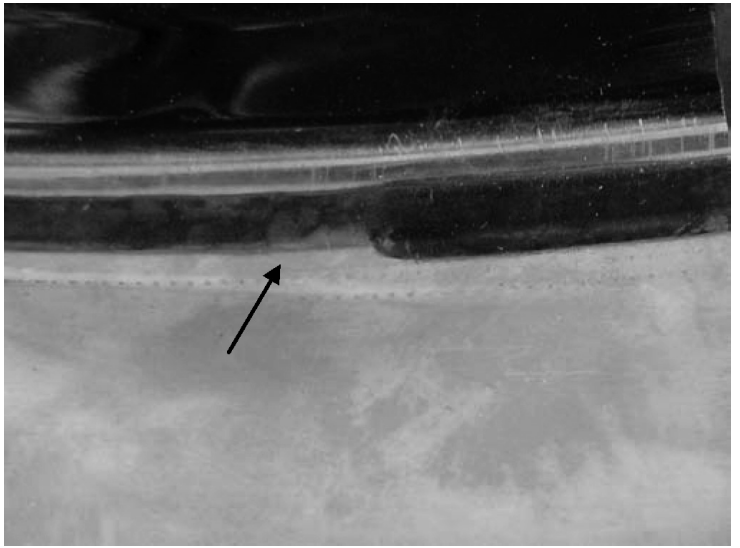

Slika 2: Detajl krožnega zvara z razširitvijo, ki jo kaže puščica Figure 2: Detail of circular weld with enlargement shown by arrow

opremljenim z videokamero Olympus DP73 in računalniškim programom za analizo Stream Motion.

Korozijske meritve so potekale na potenciostatu/ galvanostatu EG\&G PAR Model 273 s trielektrodno korozijsko celico, pri čemer je bila uporabljena tehnika potenciodinamske polarizacije. Korozijsko so bile preizkušene tri osnovne pločevine (Tabela 1) in dve vrsti zvara (prečni in krožni zvar).

\section{REZULTATI}

\subsection{Metalografski pregled zvarov}

Iz vzorcev sta bila pripravljena prečna prereza obeh vrst zvarov, prečnega zvara in krožnega zvara.

Pregled izgleda površine zvara je pokazal, da se pri obeh vrstah zvarov na začetku zvara oziroma na mestu združevanja zvarov pojavi razširjeno področje (Slika 2).

$\mathrm{V}$ prečnem preseku prečnega zvara je opazna črta, ki izgleda kot nezveznost v zvaru (Slika 3). Črta se prične na površini, teče pod kotom $45^{\circ}$ do sredine zvara, nato teče vzporedno s površino in se nato zopet pod kotom $45^{\circ}$ obrne proti nasprotni površini zvara.

Metalografski pregled je pokazal, da gre za nespojeno področje med pločevinama in da se kristalna zrna na prehodu v zvar povečajo. Pri feritnem nerjavnem jeklu se v zvaru zrna lahko povečajo, ker to jeklo nima faznih pazljivo izvajati proces varjenja.

Na Sliki 4 je prikazan prehod iz zvara v toplotno vplivano cono na preseku prečnega zvara, na Sliki 5 pa mikrostruktura $\mathrm{v}$ sredini enojnega (čelnega) prečnega zvara. Iz Slike 5 je razvidno, da so zrna v zvaru večja kot premen pri ohlajanju in ogrevanju, zato je potrebno 

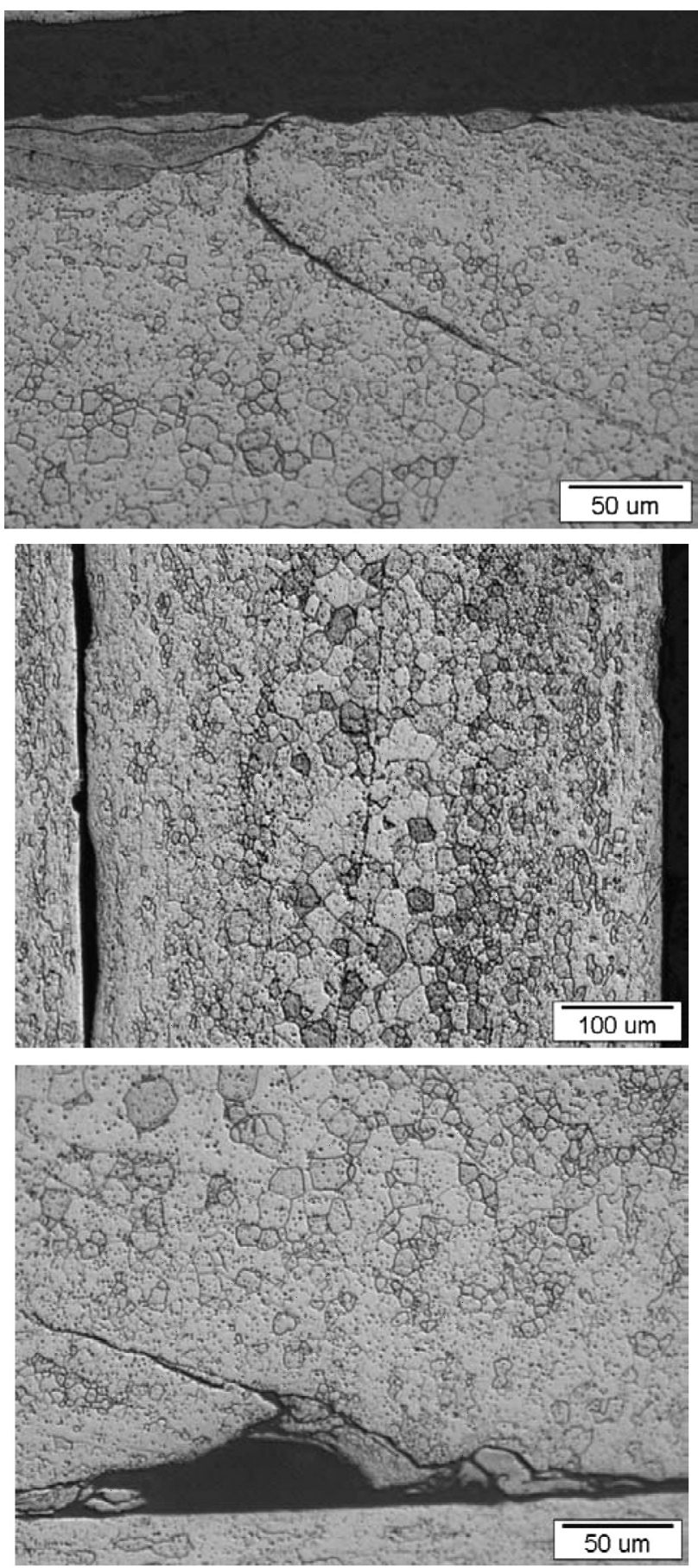

Slika 3: Detajl preseka skozi prečni zvar: a) zgornja površina, b) sredina in c) spodnja površina. Jeklo X6Cr17, jedkano z Vilella jedkalom.

Figure 3: Detail of cross-section of cross weld: a) upper surface, b) middle and c) lower surface. Steel X6Cr17, etched with Vilella's reagent.

v osnovni mikrostrukturi jekla $\mathrm{X} 6 \mathrm{Cr} 17$, ki je prikazana na Sliki 6.

Značilnosti mikrostrukture krožnega zvara so prikazane na Slikah od 7 do 9.

V posameznih delih zvara so opazne nezveznosti, kjer ni prišlo do popolne pretalitve vsega materiala.

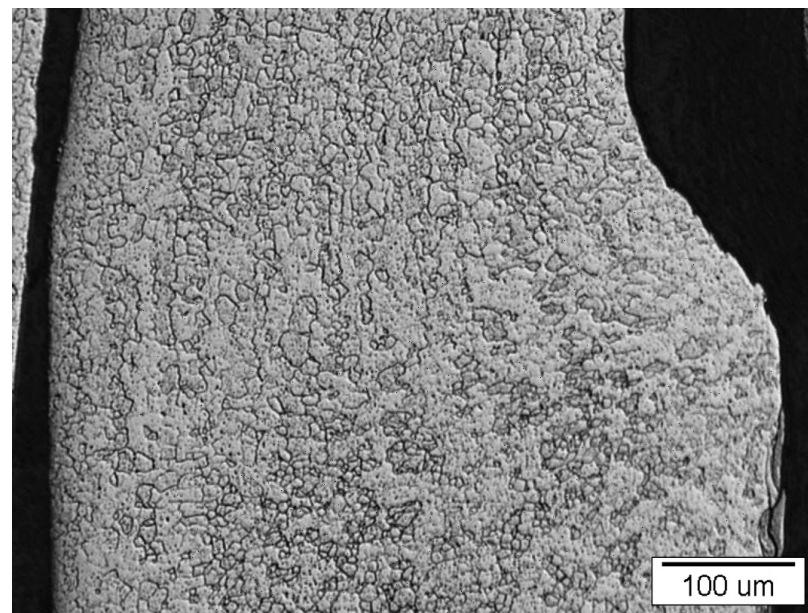

Slika 4: Presek prečnega zvara. Prehod iz zvara v toplotno vplivano cono. Jeklo X6Cr17, jedkano z Vilella jedkalom.

Figure 4: Cross-section of the cross weld. Transition from weld to heat-affected zone. Steel X6Cr17, etched with Vilella's reagent.

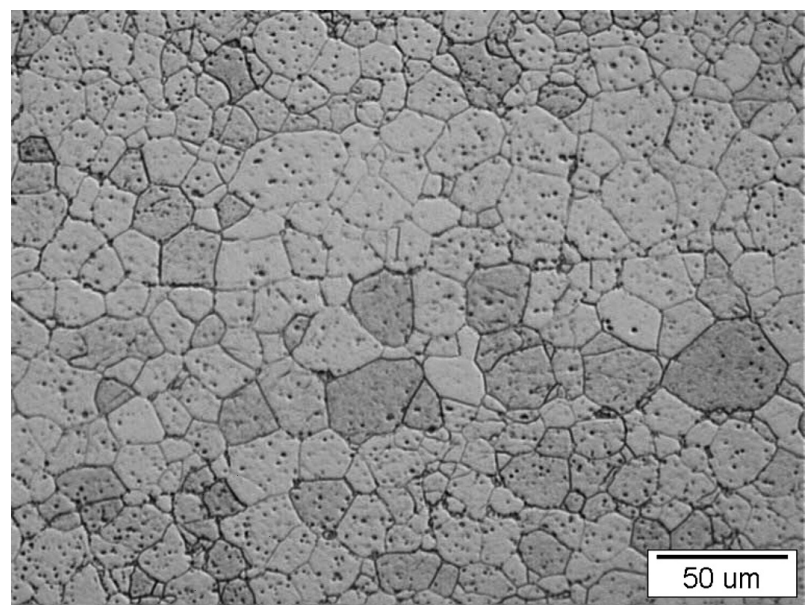

Slika 5: Mikrostruktura v sredini prečnega zvara. Jeklo X6Cr17, jedkano z Vilella jedkalom.

Figure 5: Microstructure in the middle of the cross weld. Steel X6Cr17, etched with Vilella's reagent.

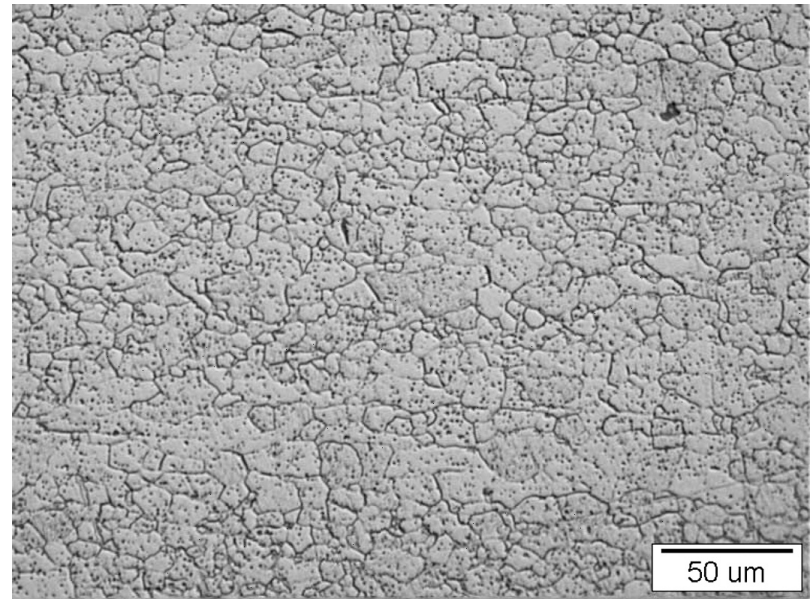

Slika 6: Mikrostruktura osnovne pločevine. Jeklo X6Cr17, jedkano z Vilella jedkalom.

Figure 6: Microstructure of base sheet material. Steel X6Cr17, etched with Vilella's reagent. 


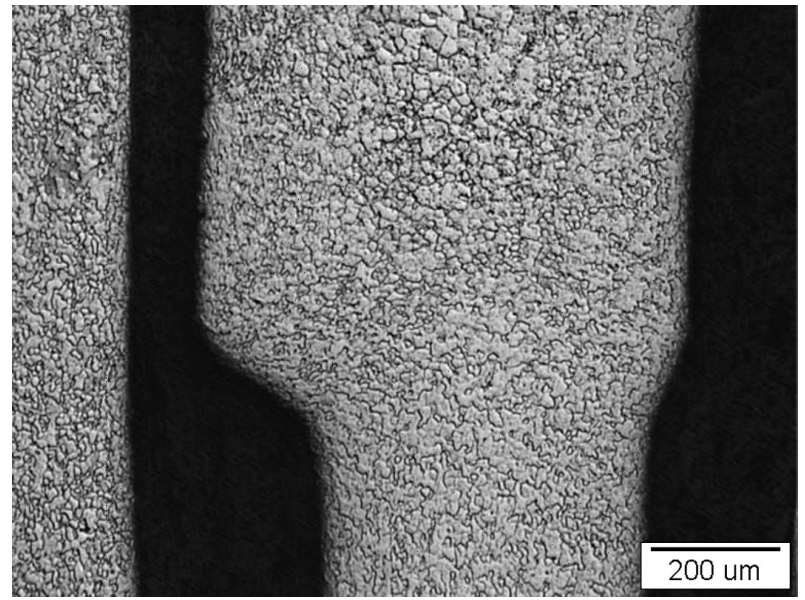

Slika 7: Prerez prehoda v krožni zvar. Jeklo X6Cr17, jedkano z Vilella jedkalom

Figure 7: Cross-section of transition to a circular weld. Steel X6Cr17, etched with Vilella's reagent
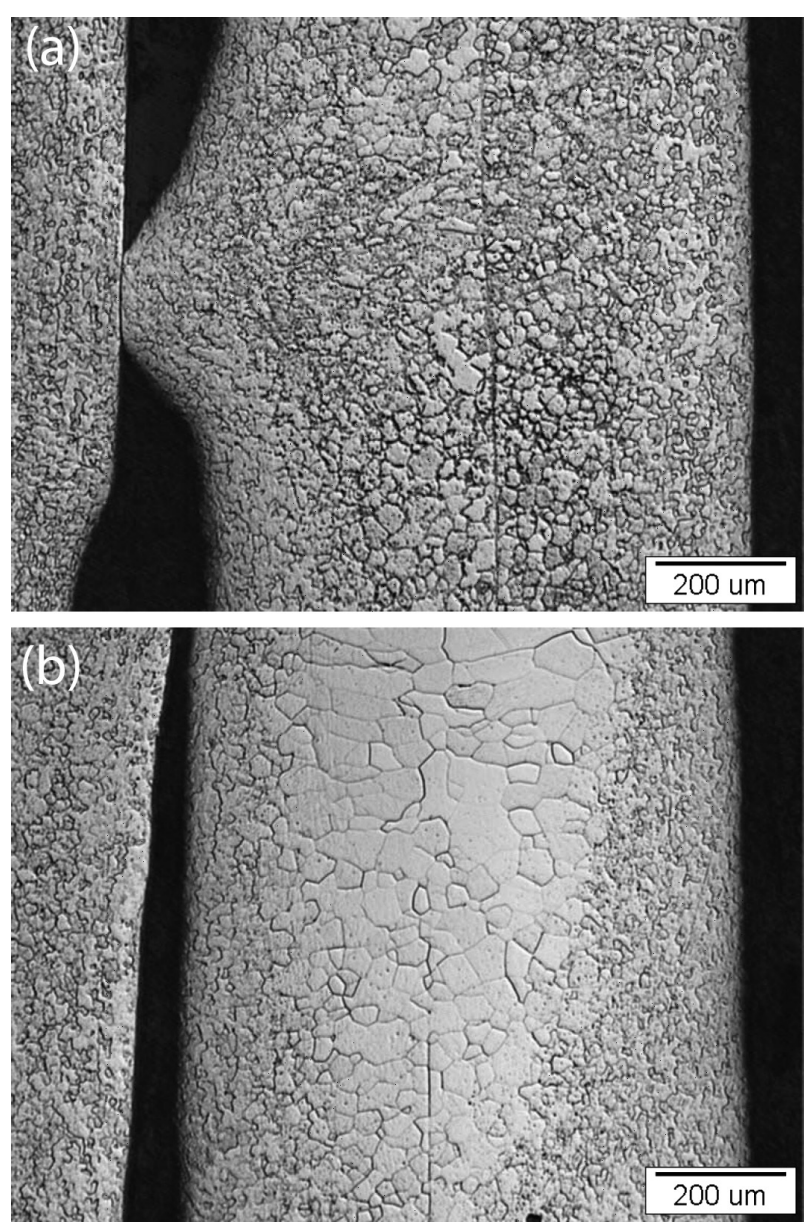

Slika 8: a) Napaka v sredini krožnega zvara in b) rast zrn. Jeklo X6Cr17, jedkano z Vilella jedkalom

Figure 8: a) Failure in the central part of a circular weld and c) grain growth. Steel X6Cr17, etched with Vilella's reagent

Poleg tega so v področju krožnega zvara, na posameznih mestih, opazna tudi povečana zrna in izločena martenzitna faza po mejah zrn. Spreminjanje mikrostrukture

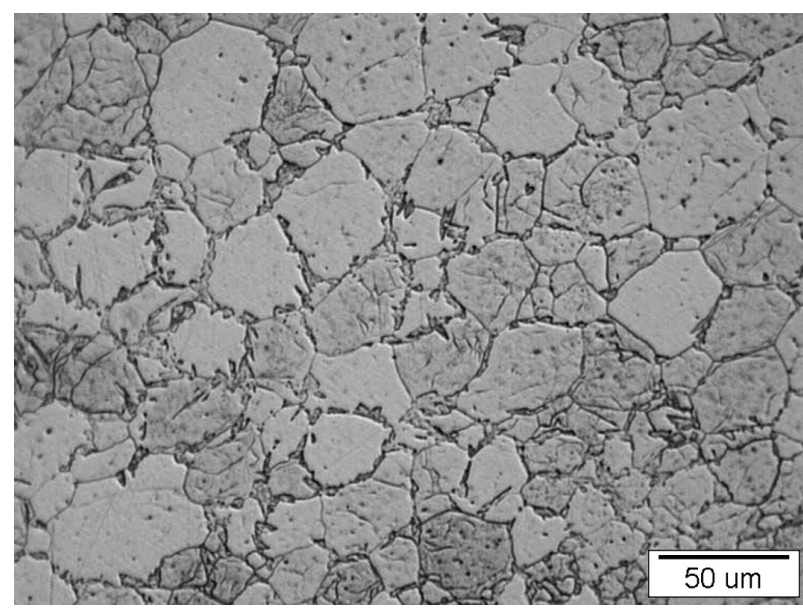

Slika 9: Mikrostruktura krožnega zvara z izločenim martenzitom po mejah zrn. Jeklo X6Cr17, jedkano z Vilella jedkalom

Figure 9: Microstructure of circular weld with a martensite phase on the grain boundaries. Steel $\mathrm{X} 6 \mathrm{Cr} 17$, etched with Vilella's reagent

zvara pomeni, da so se spreminjali parametri med postopkom varjenja.

Značilnosti obeh vrst zvarov kažeta, da bi bilo potrebno izboljšati, oziroma optimirati izvedbo varjenja.

\subsection{Korozijske preiskave}

Korozijski preskusi so bili izvedeni v dveh medijih, ki se jih uporablja pri funkcionalnih meritvah na feritnem nerjavnem jeklu, pri temperaturah $60{ }^{\circ} \mathrm{C}$ in $90{ }^{\circ} \mathrm{C}$. Korozijski medij oz. raztopino smo pripravili iz dveh praškov $\mathrm{z}$ oznako IEC-A base in Na-perborate tetrahydrate in to na naslednji način:

Raztopina 1: $10 \mathrm{~g} \mathrm{IEC/L} \mathrm{H}_{2} \mathrm{O} \mathrm{s} \mathrm{pH} \mathrm{10,5} \mathrm{pri} \mathrm{temperaturi}$ $60{ }^{\circ} \mathrm{C}$

Raztopina 2: 8 g IEC + 2 g Na-perborata/ $/ \mathrm{H}_{2} \mathrm{O}$ pH 11, pri temperaturi $90{ }^{\circ} \mathrm{C}$

Vse korozijske meritve so potekale na potenciostatu/ galvanostatu $\mathrm{z}$ uporabo tehnike potenciodinamske polarizacije. Ta tehnika postopnega dvigovanja potenciala na enoto časa, $\mathrm{k}$ bolj pozitivnim vrednostim, spreminja korozijsko stabilnost kovine. Z naraščanjem potenciala postaja material termodinamsko vedno manj stabilen, kar pomeni, da narašča tudi korozijski tok, ki je merilo za stopnjo korozije. Tako spoznamo splošno kvalitativno sliko o obnašanju materiala v nekem mediju. Iz oblike anodnega dela krivulje lahko sklepamo o korozijski odpornosti, morebitni pasivaciji, potencialu preboja in podobno. ${ }^{10} \mathrm{Iz}$ Taflovega dela krivulje $( \pm 250 \mathrm{mV}$ glede na $E_{\text {kor }}$ ) lahko izračunamo tudi korozijsko hitrost in polarizacijsko upornost, s tem pa stopnjo korozije.

Za delovno elektrodo so bili uporabljeni naslednji vzorci:

Vzorec 1 (dno kadi - X6Cr17)

Vzorec 2 (krožni zvar - X6Cr17)

Vzorec 3 (prečni zvar - X6Cr17)

Vzorec 4 (malo ogljično jeklo kvalitete DC01) 
Vzorec 5 (jeklo X2CrTi17).

Izpostavljena površina elektrodne reakcije na delovni elektrodi je bila $1 \mathrm{~cm}^{2}$, referenčna elektroda je bila nasičena kalomelova elektroda in pomožna elektroda je bila grafitna palica.

V Tabeli 1 so podani rezultati potenciodinamskih meritev za korozijsko hitrost, korozijski potencial, korozijski tok in polarizacijska upornost petih preiskovanih vzorcev v raztopini 1, v Tabeli 2 pa rezultati za raztopino 2 .

Na Slikah 10 in $\mathbf{1 1}$ so prikazane potenciodinamske polarizacijske krivulje preiskovanih vzorcev v raztopini 1 pri $60{ }^{\circ} \mathrm{C}$ in raztopini 2 pri $90{ }^{\circ} \mathrm{C}$.

Tabela 1: Rezultati potenciodinamskih meritev petih vzorcev v raztopini 1 , pri $60^{\circ} \mathrm{C}$

Table 1: Results of potentiodynamic measurements of five samples in solution 1 , at $60{ }^{\circ} \mathrm{C}$

\begin{tabular}{|c|c|c|c|c|}
\hline Vzorec & $\begin{array}{c}\text { Korozijska } \\
\text { hitrost }\end{array}$ & $E(I=0)$ & $I_{\text {corr }}$ & $R_{\mathrm{p}}$ \\
\hline $\begin{array}{c}\text { 1 (dno kadi) } \\
\text { X6Cr17 }\end{array}$ & $\begin{array}{c}0,0013 \\
\mathrm{~mm} / \text { leto }\end{array}$ & $-151,3 \mathrm{mV}$ & $120,0 \mathrm{nA}$ & $277,0 \mathrm{k} \Omega$ \\
\hline $\begin{array}{c}2 \text { (krožni zvar) } \\
\text { X6Cr17 }\end{array}$ & $\begin{array}{c}0,036 \\
\mathrm{~mm} / \text { leto }\end{array}$ & $-242,1 \mathrm{mV}$ & $3282 \mu \mathrm{A}$ & $13,16 \mathrm{k} \Omega$ \\
\hline $\begin{array}{c}3 \text { (prečni zvar) } \\
\text { X6Cr17 }\end{array}$ & $\begin{array}{c}0,015 \\
\mathrm{~mm} / \text { leto }\end{array}$ & $-281,5 \mathrm{mV}$ & $1399 \mu \mathrm{A}$ & $27,26 \mathrm{k} \Omega$ \\
\hline 4 (DC01) & $\begin{array}{c}0,059 \\
\mathrm{~mm} / \text { leto }\end{array}$ & $-340,5 \mathrm{mV}$ & $6132 \mu \mathrm{A}$ & $5382 \mathrm{k} \Omega$ \\
\hline 5 (X2CrTi17) & $\begin{array}{c}0,0013 \\
\mathrm{~mm} / \text { leto }\end{array}$ & $-240,8 \mathrm{mV}$ & $116,1 \mathrm{nA}$ & $310,5 \mathrm{k} \Omega$ \\
\hline
\end{tabular}

Preiskave potenciodinamske polarizacije petih preiskovanih vzorcev so pokazale, da sta vzorec 1 (dno kadi $\mathrm{X} 6 \mathrm{Cr} 17)$ in vzorec 5 (X2CrTi17) v raztopini 1 pri $60{ }^{\circ} \mathrm{C}$ korozijsko najbolj odporna, kar je razvidno iz najnižjih vrednosti korozijskih hitrosti $(1,3 \mu \mathrm{m} /$ leto $)$ in najvišjih
Tabela 2: Rezultati potenciodinamskih meritev petih vzorcev v raztopini 2 pri $90{ }^{\circ} \mathrm{C}$

Table 2: Results of potentiodynamic measurements of five samples in solution 2 at $90{ }^{\circ} \mathrm{C}$

\begin{tabular}{|c|c|c|c|c|}
\hline Vzorec & $\begin{array}{c}\text { Korozijska } \\
\text { hitrost }\end{array}$ & $E(I=0)$ & $I_{\text {corr }}$ & $R_{\mathrm{p}}$ \\
\hline $\begin{array}{c}\text { 1 (dno kadi) } \\
\text { X6Cr17 }\end{array}$ & $\begin{array}{c}0,059 \\
\mathrm{~mm} / \text { leto }\end{array}$ & $-21,62 \mathrm{mV}$ & $5442 \mu \mathrm{A}$ & $6063 \mathrm{k} \Omega$ \\
\hline $\begin{array}{c}2 \text { (krožni zvar) } \\
\text { X6Cr17 }\end{array}$ & $\begin{array}{c}0,411 \\
\mathrm{~mm} / \mathrm{leto}\end{array}$ & $-40,08 \mathrm{mV}$ & $37,77 \mu \mathrm{A}$ & $1137 \mathrm{k} \Omega$ \\
\hline $\begin{array}{c}3 \text { (prečni zvar) } \\
\text { X6Cr17 }\end{array}$ & $\begin{array}{c}0,351 \\
\mathrm{~mm} / \text { leto }\end{array}$ & $-78,87 \mathrm{mV}$ & $32,22 \mu \mathrm{A}$ & $781,1 \Omega$ \\
\hline 4 (DC01) & $\begin{array}{c}8,167 \\
\mathrm{~mm} / \text { leto }\end{array}$ & $-434,4 \mathrm{mV}$ & $847,4 \mu \mathrm{A}$ & $56,51 \Omega$ \\
\hline 5 (X2CrTi17) & $\begin{array}{c}0,049 \\
\mathrm{~mm} / \text { leto }\end{array}$ & $-4851 \mathrm{mV}$ & $4568 \mu \mathrm{A}$ & $7700 \mathrm{k} \Omega$ \\
\hline
\end{tabular}

vrednosti polarizacijske upornosti $R_{\mathrm{p}}(277-310 \mathrm{k} \Omega)$. Pričakovano je korozijsko najmanj stabilen vzorec 4 (malo ogljično jeklo), s 45- do 60-krat slabšo korozijsko odpornostjo, medtem ko sta vzorca 2 in 3 (krožni zvar X6Cr17 in prečni zvar -X6Cr17) dokaj primerljiva, a še vedno za en velikostni razred manj korozijsko odporna kot osnovni material. Domnevamo, da je to posledica razlike v velikosti zrn in značilnosti strjevalne strukture zvarov ter pojava martenzitne faze po mejah zrn. Vidimo lahko tudi, da je prečni zvar 2-krat korozijsko bolj odporen kot krožni zvar, kjer se opazi v zvaru martenzitna faza po mejah zrn. V raztopini 2 pri $90{ }^{\circ} \mathrm{C}$ so vrednosti korozijske hitrosti 10 -krat višje, kar je posledica bolj agresivnega medija. V primeru vzorca 4 (malo ogljično jeklo) je ta pojav še posebej izrazit, kjer se ocenjena korozijska hitrost poveča kar za dva velikostna razreda na približno $8 \mathrm{~mm} /$ leto. Tudi v raztopini 2 sta korozijsko najbolj stabilna vzorca 1 (X6Cr17) in 5 (X2CrTi17) z ocenjeno korozijsko hitrostjo 50-60
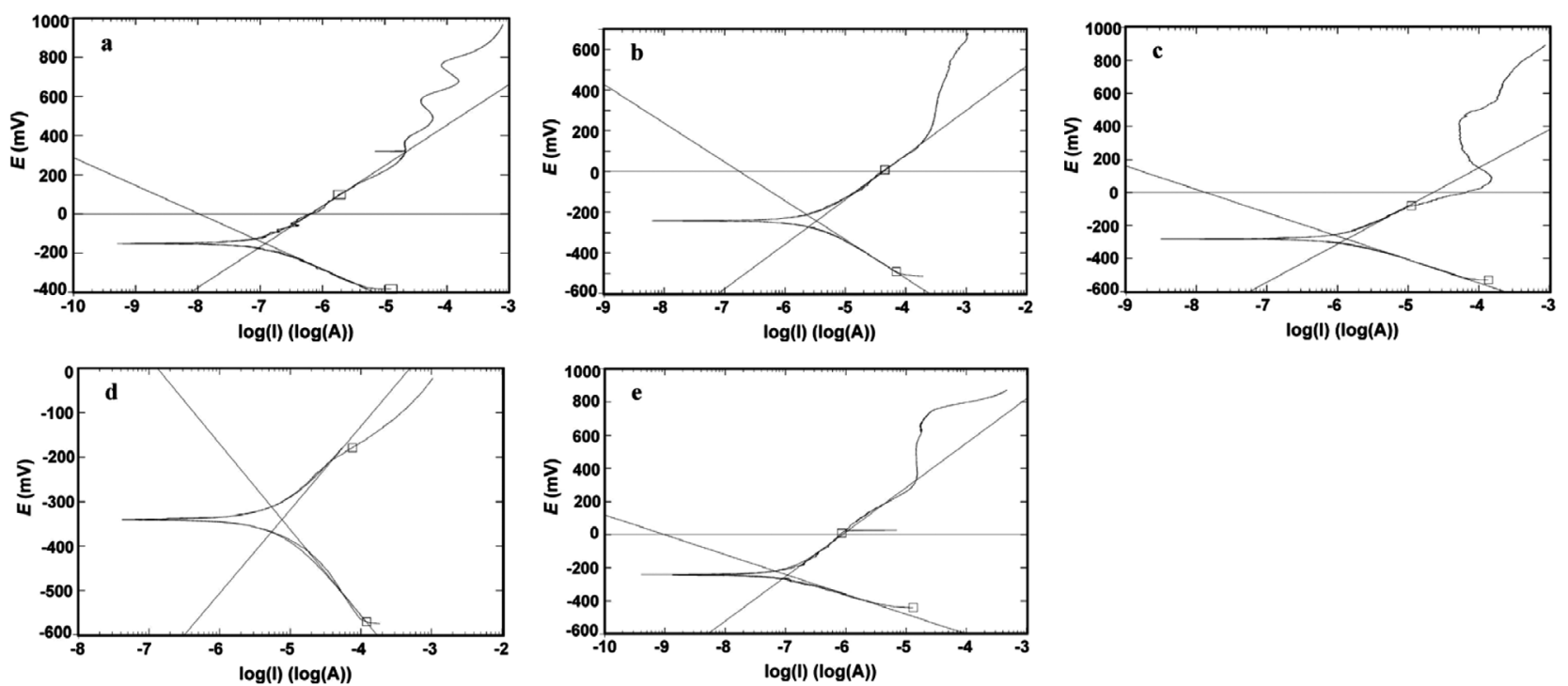

Slika 10: Potenciodinamska krivulja v raztopini 1 pri $60{ }^{\circ} \mathrm{C}$ : a) X6Cr17 - dno kadi, b) X6Cr17 - krožni zvar, c) X6Cr17 - prečni zvar, d) maloogljično jeklo CD01, EN10130 in e) primerjalno jeklo X2CrTi17

Figure 10: Potentiodynamic curve in solution 1 at $60{ }^{\circ} \mathrm{C}$ : a) $\mathrm{X} 6 \mathrm{Cr} 17$ - bottom of the tub, b) X6Cr17 - circular weld, c) X6Cr17 - cross weld, d) low-carbon steel CD01, EN10130 and e) X2CrTi17 comparative steel 

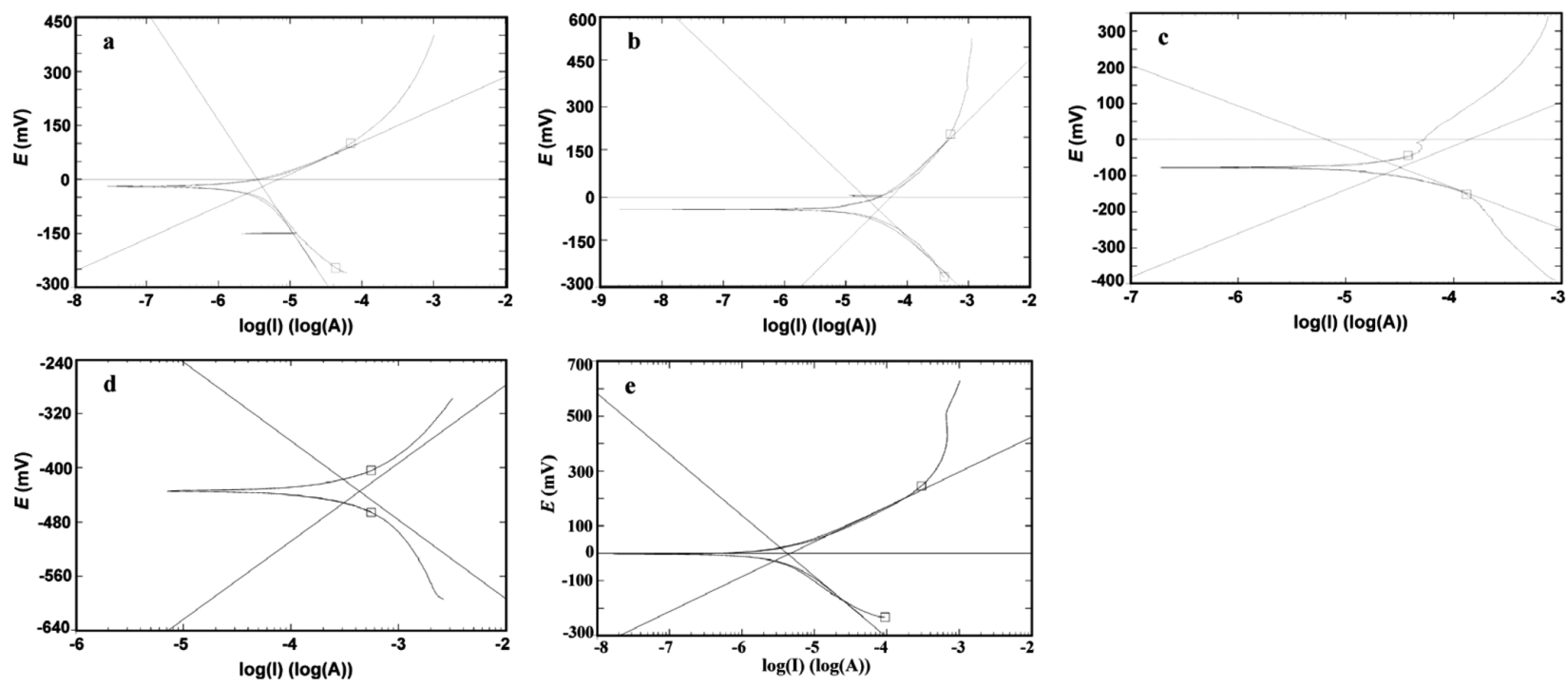

Slika 11: Potenciodinamska krivulja v razopini 2 pri $90{ }^{\circ} \mathrm{C}$ : a) X6Cr17 - dno kadi, b) X6Cr17 - krožni zvar, c) X6Cr17 - prečni zvar, d) maloogljično jeklo CD01 po standardu EN10130 in e) primerjalno jeklo X2CrTi17

Figure 11: Potentiodynamic curve in solution 2 at $90{ }^{\circ} \mathrm{C}$ : a) bottom of the tub, b) circular weld, c) cross weld, d) low-carbon steel CD01, EN10130 and e) X2CrTi17 comparative steel

$\mu \mathrm{m} /$ leto in polarizacijsko upornostjo 6-7 $\mathrm{M} \Omega$, najmanj pa vzorec 4 . Med vzorcema 2 in 3 pa v raztopini 2 praktično ni razlik, še vedno pa ne dosegata korozijske odpornosti osnovnega materiala (vzorec 1).

Med korozijskim preskusom nobeden od preiskovanih vzorcev ni pokazal izrazite pasivacije površine.

\section{ZAKLJUČKI}

$\mathrm{Na}$ podlagi primerjave narejenih raziskav zvarov in pločevin lahko postavimo naslednje zaključke:

Zvari, tako prečni kot krožni, so izvedeni slabo, saj material ni pretaljen po vsej dolžini zvara. Potrebno bo tehnološko optimiranje tehnologije izvedbe varjenja.

Razlike v mikrostrukturi in velikosti zrn ter nespojena mesta v zvaru kažejo, da so se procesni parametri med varjenjem spreminjali.

Izvršene korozijske preiskave $\mathrm{v}$ dveh medijih in pri dveh temperaturah so pokazale, da sta na korozijo v obeh primerih najbolj odporna dno kadi iz feritnega nerjavnega jekla X6Cr17 in primerjalno jeklo X2CrTi17. Na mestu zvara se korozijska odpornost materiala zmanjša za cel velikostni razred.

Slabša korozijska odpornost krožnega zvara je posledica nastanka martenzitne faze po mejah zrn v zvaru.

Od preiskovanih vzorcev je korozijsko najmanj stabilen vzorec maloogljičnega jekla.

Pri nobenem od preiskovanih vzorcev se med korozijskim preizkusom v dveh korozijskih medijih ni pokazala izrazita pasivacija površine.

\section{LITERATURA}

${ }^{1}$ A. Talja, M. Torkar, Lap shear tests of bolted and screwed ferritic stainless steel connections, Thin-walled Structures, 83 (2014), 157-168, doi:10.1016/j.tws.2014.01.016

${ }^{2}$ Structural design of cold worked austenitic stainless steel, Final Report, Technical Steel Research, Steel products and application for building construction and industry, Directorate - General for Research, European Commission, Contract No. 7210-PR/318, 2006

${ }^{3}$ K. H. Jo, J. H. Kim, K. M. Kim, I. S. Lee, S. J. Kim, Development of a new cost effective $\mathrm{Fe}-\mathrm{Cr}$ ferritic stainless steel for SOFC interconnect, International Journal of Hydrogen Energy 40 (2015) 30, 9523 9529, doi:10.1016/j.ijhydene.2015.05.125

${ }^{4}$ I. Arrayagon, F. Picci, E. Mirambell, E. Real, Interaction of bending and axial load for ferritic stainless steel RHS columns, Thin-Walled Structures, 91 (2015), 96-107 doi:10.1016/j.tws.2015.02.012

${ }^{5}$ M. Cortie, M. du Toit, Stainless Steels, Ferritic, Reference Module in Materials Science and Materials Engineering, (2016), doi:10.1016/ B978-0-12-803581-8.02501-7

${ }^{6}$ G. M. Reddy, S. D. Meshran, Grain refinement in ferritic stainless weld through magnetic arc oscillations and its effect on tensile property, Indian Welding Journal, 39 (2006) 3, 35-41

${ }^{7}$ G. M. Reddy, T. Mohandas, Explorative studies on grain refinement of ferritic stainless steel welds, Journal of Materials Science Letters, 20 (2001) 8, 721-723

${ }^{8}$ M. O. H. Amuda, S. Mridha, An Overview of Sensitization Dynamics in Ferritic Stainless Steel Welds, International Journal of Corrosion, Volume 2011 (2011), 1-9, doi:10.1155/2011/305793

${ }^{9}$ A. K. Lakshminarayanan, K. Shanmugam, V. Balasubramanian, Effect of Autogenous Arc Welding Processes on Tensile and Impact Properties of Ferritic Stainless Steel Joints, Journal of Iron and Steel Research, International, 16 (2009) 1, 62-68

${ }^{10}$ Corrosion Mechanisms in Theory and Practice, 3rd Ed., Ed. Philippe Marcus, 2012 